\title{
PESANTREN AMTSILATI SEBAGAI ROLE MODEL PENDIDIKAN BERBASIS ANTI RADIKALISME DI JEPARA
}

\author{
Azzah Nor LailaI) \& Fathur Rohman2) \\ FTIK Universitas Islam Nahdlatul Ulama (UNISNU) Jepara \\ I) azzah@unisnu.ac.id \\ 2) fathur_rohman@unisnu.ac.id
}

\begin{abstract}
The growth of radical religious and political thought developed in Indonesia and become a serious threat to the nation. It is marked by still a lot of data of radical action and terror in Indonesia. Treatment and prevention of the spread of radical requires active participation of all parties. In that case, the role of educational institutions is very significant to help stop the rate of radicalism. Therefore, this research is trying to find the design of Islamic education based on anti radicalism, as well as portrait of Islamic educational institutions that implement antiradicalism based education system. This research is included in this type of qualitative research. While in terms of methods, this study includes case studies. The case is the subject of study in this research is the implementation of Islamic education in boarding Amtsilati anti radicalism Bangsri Jepara. Educational anti radicalism is implemented with two models, namely classical and non classical. As a boarding school with salaf and modern system, PP. Darul Falah was quite serious in printing his santri into moderate Muslims. This is evidenced by the existence of learning that is focused on anti-radicalism materials that must be followed by santri.
\end{abstract}

Keywords: education, anti radicalism, Amtsilati Boarding School.

Abstrak

Pertumbuhan pemikiran keagamaan maupun politik yang berkarakter radikal berkembang di Indonesia serta menjadi ancaman serius bangsa. Hal itu ditandai dengan masih banyaknya data aksi radikal dan teror di Indonesia. Penanganan dan pencegahan penyebaran paham radikal membutuhkan peran aktif berbagai pihak. Dalam hal tersebut, peran lembaga pendidikan sangat signifikan untuk membantu menghentikan laju radikalisme. Untuk itu penelitian ini berusaha menemukan desain pendidikan Islam berbasis anti radikalisme, serta potret lembaga pendidikan Islam yang menerapkan sistem pendidikan berbasis anti radikalisme. Fokus kajian penelitian ini pada pesantren Amtsilati Bangsri Jepara. Bagaimana konsep pendidikan Islam anti radikalisme itu sendiri, bagaimana pendidikan berbasis anti radikalisme yang telah diterapakan di pesantren Amtsilati Bangsri Jepara. Pendidikan anti radikalisme dilaksanakan dengan dua model, yaitu klasikal dan non klasikal. Sebagai pesantren dengan sistem salaf dan modern, PP. Darul Falah cukup serius dalam mencetak santri-santrinya menjadi muslim yang moderat. Hal ini dibuktikan dengan adanya pembelajaran yang difokuskan pada materi-materi anti radikalisme yang wajib diikuti santri.

Kata Kunci: Pendidikan, Anti Radikalisme, Pesantren Amtsilati. 


\section{A. PENDAHULUAN}

Pertumbuhan pemikiran keagamaan maupun politik yang berkarakter radikal berkembang di Indonesia serta menjadi ancaman serius bangsa. Hal itu ditandai dengan masih banyaknya data aksi radikal dan teror di Indonesia. Diantaranya, pada tahun 20 II muncul aksi bom buku, bom bunuh diri di Masjid Mapolresta Cirebon, bom bunuh diri di Kepunton Solo. Tahun 2012, peristiwa teror bom terjadi di pos penjagaan polisi daerah Solo. Tahun 2013, perburuan Densus 88 terhadap jaringan teroris Poso di Makassar. Tahun 20I4, penembakan terhadap dugaan pelaku teroris di Ciputat Banten (Rokhmad, 20I4). Tahun 2016, serangan bom di kawasan Sarinah J1. MH. Thamrin Jakarta pada bulan Januari, selanjutnya bulan Juli terjadi bom bunuh diri di Mapolresta Solo (Jazuli, 2016).

Peristiwa teror dan radikal tersebut berdampak pada keresahan dan rasa tidak aman bagi masyarakat Indonesia. Ironisnya, peristiwa atau tindakan ekstrim tersebut disinyalir bahwa pelaku merupakan oknum dari umat Islam. Hal itu didasarkan pada beberapa nama pelaku yang memiliki nama awal Ahmad atau Muhammad serta beridentitas muslim. Kelompok tersebut kemudian dikenal dengan kelompok Islam radikal yang menganut paham radikalisme. Hal itu dijadikan celah atau dasar munculnya pandangan negatif terhadap Islam. Islam dianggap sebagai agama yang membenarkan tindakan kekerasan atau terorisme.

Masalah radikalisme serta terorisme tidak bisa dipisahkan dari faktor lingkungan sosial, politik, ekonomi, maupun budaya dimana ideologi tersebut tumbuh serta berkembang. Terorisme atau aksi radikal merupakan hasil proses radikalisasi mulai level individu sampai kelompok. Pada kelompok teroris yang mengatasnamakan agama, proses tersebut melalui beberapa tahapan. Pertama, praradikalisasi yakni interaksi antara predisposisi individu dengan lingkungan. Kedua, identifikasi diri, komitmen, indoktrinasi, dan ideologisasi jihad.

Kalangan Islam radikal meyakini bahwa perbuatan radikal yang mereka lakukan, seperti aksi pengeboman, teror, perlawanan terhadap paham lain yang berbeda dengan ajarannya merupakan bagian dari wujud aktualisasi doktrin jihad dalam Islam (Kasjim, 2009).
Doktrin itu menguatkan anggapan sebagian penganut paham Islam radikal bahwa melakukan jihad dengan pembunuhan dapat membuahkan kesyahidan.

Aliran atau kelompok yang dianggap menganut paham radikalisme muncul dan tersebar di beberapa daerah Indonesia. Seperti Lembaga dakwah Islam Indonesia yang dikenal dengan LDII, Front pembela Islam yang dikenal dengan FPI, Salafi Jihadi yang dikenal dengan JI, Negara Islam Indonesia yang dikenal NII, Hizbut Tahrir Indonesia yang dikenal dengan sebutan HTI, Jamaah Tauhid Wal Jihad yang disingkat TWJ, Forum Kajian Islam Millah Ibrahim atau FKIMI, dan beberapa kelompok lainnya (Tim Peneliti Kemenag Jateng, 2015). Beberapa aliran tersebut disinyalir memiliki doktrin yang mengandung unsur radikal dan fanatik buta pada paham masing-masing.

Berdasarkan catatan beberapa kelompok atau aliran tersebut, Badan Nasional Penanggualangan Terorisme mengklasifikasi menjadi lima tipe kelompok radikal. Pertama, kelompok yang radikal dalam hal gagasannya, seperti Hizbut Tahrir Indonesia, Majlis Mujahidin Indonesia, dan lainnya. Kedua, kelompok radikal tetapi non teroris seperti Front Pembela Islam. Ketiga, kelompok radikal milisi contohnya antara lain kelompok Laskar Jihad. Keempat, kelompok radikal separatis seperti kelompok Negara Islam Indonesia. Kelima, kelompok radikal teroris seperti Jama'ah Islamiyyah, dan lainnya (Rokhmad, 20I4: 28).

Pertumbuhan serta perkembangan kelompok radikal maupun penyebaran pahamnya perlu ditangani secara serius. Dalam hal keamanan dan penangkapan pelaku, kepolisian menjadi tumpuan pengemban tugas tersebut. Namun penyelesaian aksi teror dan radikal tidak hanya cukup melalui penangkapan pelaku saja. Akan tetapi hal terpenting lainya adalah pemutusan penyebaran paham, penanggulangan, pencegahan, serta pelurusan ideologi atau kepercayaan agar masyarakat tidak mudah mengikuti arus paham radikalisme yang menjadi bahaya laten bagi masyarakat. Oleh karena itu, pada tahun 2010 pemerintah mengeluarkan Peraturan Presiden Nomor 46 tahun 2010 tentang pembentukan Badan Nasional Penanggulangan Terorisme (BNPT) (Rokhmad, 20I4).

Peran aktif berbagai pihak dalam menangani 
problem radikalisme sangat diperlukan. Sehingga gerak radikalisme dan terorisme menjadi sempit serta menyurut, bahkan bila perlu dapat hilang sama sekali. Dalam hal tersebut, peran lembaga pendidikan sangat signifikan untuk membantu menghentikan laju radikalisme. Untuk membekali masyarakat dan generasi muda agar tidak mudah menganut ideologi radikalisme dan tidak bersikap radikal, dengan merancang serta mengaplikasikan pengajaran dan pendidikan berbasis anti radikalisme.

Meskipun di lain pihak lembaga pendidikan juga dianggap berpeluang menjadi penyebar paham radikal. Hal itu dapat dilihat dengan mulai muncul beberapa lembaga pendidikan Islam yang dirintis oleh beberapa ormas Islam berbasis radikal. Diantara cirinya adalah identik dengan budaya Islam Timur Tengah, berpaham tekstualis dalam memahami ajaran Islam, menggunakan istilah khas Arab misalnya daurah, halaqah, dan lainnya (Muqayyidin, 2013). Selain itu pesantren terkadang juga dianggap sebagai lembaga yang menerapkan serta mengajarkan ajaran fundamentalis, sehingga rentan berujung pada paham maupun doktrin radikalisme. Hal itu dikuatkan dengan adanya temuan beberapa pelaku terror dan radikal adalah lulusan salah satu pesantren atau lembaga Islam yang bergaris keras.

Namun tidak semua lembaga pendidikan Islam dapat dikatakan sumber penyebaran paham radikal. Buktinya ada beberapa lembaga pendidikan Islam yang mengedepankan toleransi, keberagaman, dan kedamaian. Diantara pesantren yang sudah merespon problem sosial tersebut adalah pesantren Amtsilati Bangsri Jepara. Pembelajaran di pesantren Amtsilati memiliki khas kajian kitab, mengajarkan kesederhanaan, dan toleransi. Selain itu, pengasuh pesantren Amtsilati juga telah menulis buku tentang cara menangkal paham radikal, dengan desain sederhana serta mudah dipahami oleh pembaca atau santri.

Pesantren Amtsilati juga termasuk pesantren yang sangat peduli tehadap usaha deradikalisasi. Baik melalui pembelajaran di pesantren, maupun dakwah tentang penanggulangan radikalisme bagi para pendidik serta masyarakat umum. Hal inilah yang mendasari penulis mengkaji pendidikan Islam di pesantren Amtsilati Bangsri Jepara sebagai role model pendidikan Islam berbasis anti radikalisme. Bagaimana konsep pendidikan Islam yang telah diterapakan di pesantren Amtsilati Bangsri Jepara.

Dalam rangka menemukan konsep tersebut, penulis menggunakan metode kualitatif, yaitu suatu kajian yang tidak menggunakan model perhitungan. Secara teknis penelitian kualitatif dapat diartikan sebagai penelitian yang secara fundamental bergantung pada pengamatan kepada manusia dalam bahasanya dan dalam peristilahannya (Moleong, 1993). Oleh karena kajian ini tidak melibatkan pada perhitungan, maka data dan hasil yang diperoleh tidak berwujud angka, tetapi uraian verbal dari semua yang dihasilkan.

Dilihat dari segi obyek yang diteliti dan teknik pengumpulan data, penelitian ini bisa dikategorikan dalam jenis penelitian lapangan (field research) yaitu riset yang dilakukan di kancah atau medan terjadinya gejala-gejala (Hadi, I995). Sementara dari segi metode, penelitian ini termasuk penelitian kasus (case study). Case Study atau studi kasus secara umum dapat diartikan sebagai metode atau strategi penelitian dan sekaligus hasil penelitian pada kasus tertentu. Studi kasus merupakan suatu jenis penelitian yang dilakukan pada suatu kesatuan sebuah sistem. Kesatuan dimaksud dapat berupa program, kegiatan, peristiwa, atau sekelompok individu yang terikat oleh tempat, waktu, atau ikatanikatan lain (Sukmadinata, 2009: 64).

Adapun bahan studi dalam penelitian ini adalah pelaksanaan pendidikan islam anti radikalisme di Pesantren Amtsilati Bangsri Jepara. Kegiatan pendidikan anti radikalisme di pesantren amtsilati, peristiwa pendidikan yang terjadi di pesantren amtsilati, atau sekelompok individu yang terikat dengan pesantren amtsilati seperti kiyai, ustadz, dan para santri. Metode analisis yang digunakan adalah analisis deskriptif kualitatif.

\section{B. PEMBAHASAN}

Pendidikan secara etimologi berasal dari bahasa Latin educare, yang artinya memasukkan sesuatu. Adapun secara istilah pendidikan merupakan proses perubahan sikap atau perilaku seseorang maupun kelompok dalam rangka berusaha mendewasakan manusia melalui pengajaran, suatu proses, dan aktfitas 
mendidik (Darmaji, 2013).

Kata pendidikan dalam al Qur'an disebutkan dengan kata rabba, yang merupakan akar kata dari tarbiyah. Karena tarbiyah berarti pendidikan (Mandhur, 1990). Selain itu, kata 'ilmu dengan beragam bentuk derivasinya terulang sebanyak 854 kali dalam al-Qur'an. Kata ini digunakan untuk arti proses mendapatkan pengetahuan dan objek pengetahuan. Dalam pandangan al-Qur'an, ilmu adalah keistimewaan yang menjadikan manusia unggul dibandingkan dengan makhluk lain guna menjalankan fungsi kekhalifahan (Shihab, 2007).

Manusia memiliki potensi meraih ilmu dan mengembangkannya atas izin Allah. Oleh karena itu, banyak ayat yang memerintahkan manusia menempuh berbagai cara untuk mewujudkan hal tersebut. AlQur'an juga menunjukkan betapa tinggi kedudukan orang yang berpengetahuan. Trial and error (cobacoba), pengamatan, percobaan dan tes kemungkinan (probability) merupakan beberapa cara yang digunakan para ilmuwan untuk meraih pengetahuan. Cara tersebut diungkapkan secara implisit dalam beberapa ayat, diantaranya ayat yang memerintahkan manusia agar melihat, berpikir, melakukan perjalanan, dan sebagainya (Shihab, 2007).

\section{Pendidikan Anti Radikalisme}

Istilah radikalisme berasal dari kata dasar radikal. Kata radikal dalam bahasa latin radix berarti akar, dan dalam bahasa Inggris radical memiliki makna ekstrim, fanatik, serta fundamental (Hornby, 2000). Sedangkan secara terminologis, radicalism berarti suatu doktrin atau praktik penganut paham radikal (Nuh, 2009). Dalam kamus bahasa Indonesia, radikalisme adalah suatu paham atau aliran tertentu yang menginginkan perubahan dengan cara keras atau ekstrim (Departemen Pendidikan dan Kebudayaan, 1990).

Radikalisme adalah suatu paham yang dibuat oleh sekelompok orang yang ingin melakukan perubahan atau pembaharuan sosial dan politik secara drastis dengan menggunakan cara kekerasan. Namun dari sudut pandang keagamaan dapat diartikan sebagai paham keagamaan yang mengacu pada fondasi agama yang sangat mendasar dengan fanatisme buta sehingga tidak jarang penganutnya menggunakan cara kekerasan dan paksaan kepada orang yang berbeda paham dengannya (Tim Penyusun Kamus, 2007).

Kelompok yang disinyalir menganut paham radikal memiliki ciri khusus. Ciri-ciri kelompok radikal secara garis besar bisa dipetakan menjadi tiga poin, yaitu; pertama, suatu kelompok yang sering mengklaim pahamnya sebagai kebenaran tunggal serta mudah menyesatkan kelompok lain yang tidak sependapat dengan paham kelompoknya. Kedua, memiliki sikap atau perilaku beragama yang lebih memprioritaskan hal-hal sekunder bahkan mengesampingkan persoalan primer. Contohnya fenomena meninggikan celana di atas mata kaki serta memanjangkan jenggot bagi lelaki, memakai cadar bagi perempuan, dan lain sebagainya. Ketiga, kelompok yang terlalu berlebihan atau ektrem dalam beragama bahkan terkadang tidak dapat menempatkan suatu perkara pada tempatnya (Rokhmad, 2012).

Pendidikan Islam anti radikalisme adalah usaha yang dilakukan secara sadar serta terencana melalui kegiatan pembelajaran agar anak didik atau siswa memiliki sikap menentang radikalisme (Masduqi, 20I2: I2). Secara sederhana pendidikan berbasis anti radikalisme merupakan suatu kegiatan pembelajaran yang mengarahkan peserta didiknya menjadi pribadi yang toleran, tidak radikal, dan cinta damai.

Implementasi pendidikan Islam anti radikalisme dalam seluruh rangkaian kegiatan pembelajaran memiliki tiga fungsi. Pertama, membentuk akhlak peserta didik yang mulia. Kedua, sebagai usaha untuk memberantas dan menghilangkan paham radikalisme beserta ruang geraknya. Ketiga, usaha menumbuhkan generasi umat Islam yang santun, toleran, tidak radikal, serta cinta damai (Masduqi, 2012: I3).

\section{Pendidikan di Pesantren Amtsilati Bangsri}

a. Sejarah Pesantren Amtsilati Bangsri

Pesantren Amtsilati terletak di dukuh Sidorejo RT 03 RW I2 Bangsri Jepara. Nama asli pesantren ini adalah Darul Falah, tetapi lebih dikenal oleh masyarakat dengan sebutan pesantren Amtsilati karena ciri khasnya yaitu metode Amtsilati. Metode Amtsilati merupakan suatu metode praktis membaca serta menguasai kitab kuning yang merupakan masterpiece KH. Taufiqul Hakim, pengasuh pesantren Amtsilati. Berdirinya PP. Darul 
Falah sendiri secara kelembagaan merupakan upaya $\mathrm{KH}$. Taufiqul Hakim untuk memberikan kemudahan dan sarana bagi para santri yang belajar Amtsilati.

Namun secara non formal, cikal bakal PP. Darul Falah sebenarnya sudah ada jauh sebelum munculnya metode Amtsilati. Bisa dikatakan awal mula sejarah PP. Darul Falah dimulai saat Kiai Taufiq, begitu ia akrab disapa, boyong dari pesantren Maskalul Huda Kajen asuhan KH. Sahal Mahfudz pada tahun 1995. Saat itu, kebetulan ada empat orang temannya yaitu Saifuddin dari Jepat Lor, Mahmudin dari Ngagel, Saiful Ulum dari Bulu Manis, dan Zainal Abidin dari Tenggeles Kudus yang sengaja ikut ke Bangsri untuk mencari pekerjaan di pengrajin meubel. Diceritakan bahwa keempat orang tersebut telah khatam dan hafal Alfiyah Ibnu Malik, tetapi belum sepenuhnya mampu memahami dan mengaplikasikan isinya. Oleh karenanya, sambil bekerja, mereka masih menyempatkan diri untuk belajar kembali di bawah bimbingan temannya sendiri, yaitu $\mathrm{KH}$. Taufiqul Hakim muda.

Setengah tahun kemudian, tepatnya pada tahun 1996, dua keponakan KH. Taufiqul Hakim yaitu Shodiqin dan Nur dari Bondo, datang untuk ikut mengaji kepadanya. Karena tidak punya tempat yang layak, kiai Taufiq meminjam sebuah rumah milik Pak Imron yang terletak tepat di depan rumahnya sebagai asrama untuk santri-santrinya tersebut. Bersama keenam orang tersebut, lalu kiai Taufiq membuka majlis ta'lim untuk anak-anak kecil di desanya dan sempat memiliki I00 orang santri. Tidak lama menempati rumah pinjaman tersebut, karena ewuh jika terus menerus pinjam rumah, akhirnya kiai Taufiq memutuskan membangun tempat sederhana untuk para santrinya. Meskipun dalam keadaan yang serba kekurangan, bukannya berkurang, malah beberapa santri dari desa lain datang untuk nyantri kepadanya.

Pada saat majlis ta'lim rintisannya mulai berkembang, ia justru memutuskan untuk mengaji dan mondok lagi. Ia pun berangkat mondok ke Pesantren Al-Manshur Popongan Klaten di bawah asuhan KH. Salman Dahlawi untuk ngaji Thariqah Naqsyabandiyyah di sana. Baru seminggu di pesantren, kabar duka datang, ayahanda Kiai Taufiq meninggal dunia. Kehilangan sang ayah sebagai tulang punggung keluarga, ternyata tidak menyurutkan langkahnya untuk belajar thariqah.
Setelah tujuh hari wafat sang ayah, iapun kembali ke Klaten dengan bekal $20 \mathrm{~kg}$ beras dan uang 50 ribu hasil sumbangan kematian dari tetangga. Meski dengan bekal terbatas, ia bertekad tidak akan pulang kampung sebelum merampungkan semua tahapan keilmuan dalam Thariqah Naqsyabandiyyah.

Setelah menyelesaikan ngaji thariqah selama IOO hari, Kiai Taufiq pulang ke Bangsri. Karena ditinggal cukup lama, majlis ta'lim yang telah dirintisnyapun bubar. Praktis hanya Shodiqin, santri yang juga keponakannya yang masih bertahan. Dari situlah kemudian, pesantren sederhana Kiai Taufiq mulai didatangi para santri lagi. Pada tahun 2000, sejumlah siswi MTs di desanya, ikut nyantri di tempat Kiai Taufiq. Hingga pada 2002 pesantren yang dirintis Kiai Taufiq secara resmi didaftarkan ke notaris dengan nama PP. Darul Falah (PPDF). Seiring meluasnya peredaran metode Amtsilati di berbagai penjuru, PP. Darul Falah juga mengalami perkembangan yang sangat pesat.

\section{b. Sistem Pendidikan Pesantren Amtsilati Bangsri}

Pendidikan di pesantren Amtsilati menyediakan beberapa pilihan program. Program pendidikan klasikal dan non klasikal. Sistem non klasikal ini digunakan dalam pengajian kitab kuning dengan metode bandongan yang dilaksanakan setiap habis subuh dan sehabis maghrib. Sedangkan model pendidikan sistem klasikal diterapkan dalam pendidikan non formal melalui pembelajaran metode Amtsilati dan Madrasah formal seperti MTs dan MA. Materi wajib yang harus dipelajari seluruh santri atau peserta didik yang belajar di lembaga pendidikan Amtsilati adalah metode membaca kitab kuning. Suatu metode praktis untuk mendalami ilmu nahwu dan shorof, sehingga kedua ilmu yang seringnya dianggap sulit menjadi mudah. Kedua ilmu tersebut menjadi ciri khas pendidikan di pesantren Amtsilati (www. amtsilatipusat.net). Karena melalui pembekalan santri dengan kedua ilmu alat tersebut, para santri atau peserta didik diharapkan dapat membaca serta memahami sumber-sumber pendidikan Islam turats yang mayoritas berbahasa Arab dan mulai banyak tidak dikenal generasi muda.

Berikut ini adalah beberapa program yang diselenggarakan di Pesantren Amtsilati: 
I Program Pemula Membaca Kitab Kuning

2 Metode Amtsilati 3 - 6 bulan

3 Program Pasca Amtsilati

4 Komunikasi Bahasa Inggris - Arab

5 Madin Amtsilati Program Wustho -'Ulya

6 Program Kilatan Amtsilati Kurang dari 3 bulan

7 Program MI Tahfidhul Qur'an (khusus putra)

8 MTs Amtsilati

9 MA Amtsilati

I0 Ekstra kurikuler Rebana \& Marching Band

c. Pendidikan Anti Radikalisme di Pesantren Amtsilati

I) Pendekatan pembelajaran

Meskipun melabeli dirinya dengan label salaf, sebenarnya PP. Darul Falah tidak sepenuhnya salaf. Hal ini bisa dilihat dalam sistem pendidikan yang digunakan, yakni model tradisional seperti pesantren atau madrasah diniyah dan model modern seperti madrasah formal. Adapun sisi kesalafan PP. Darul Falah salah satunya bisa dilihat dari sistem pendidikan dan kurikulum yang diterapkan di pesantrennya. Seperti pesantren pada umumnya, sistem pembelajaran yang digunakan masih menggunakan sistem non klasikal. Sistem ini digunakan dalam pembelajaran kitab kuning yang dikaji langsung oleh pengasuh.

Demikian halnya, pendidikan anti radikalisme di PP. Darul Falah juga dilaksanakan dengan pendekatan salaf, yaitu dengan metode bandongan seperti umumnya pengajian kitab kuning di pesantren. Pengajian ini diampu langsung oleh pengasuh yaitu KH. Taufiqul Hakim dan wajib diikuti oleh semua santri setiap habis subuh dan setelah maghrib. Dilihat dari kacamata pendekatan pembelajaran, maka metode bandongan ini lebih cenderung berpusat pada guru (teacher centered). Guru lebih banyak melakukan kegiatan mengajar dengan bentuk ceramah. Sementara siswa sebatas mendengarkan, mencatat, memahami penjelasan guru. Guru menjadi pusat pembelajaran dan seolah-olah menjadi satusatunya sumber ilmu.

Selain lewat bandongan, pendidikan anti radikalisme juga dilaksanakan dengan sistem klasikal di madrasah diniyah pasca Amtsilati. Madrasah diniyah pasca Amtsilati adalah madrasah diniyah yang dikhususkan bagi para santri yang telah selesai menempuh pendidikan metode Amtsilati. Pembelajaran di kelas bisa menggunakan metode yang bervariasi, meliputi bandongan, sorogan, dan takroran. Dengan demikian, pembelajaran di kelas madrasah diniyyah ini lebih cenderung menggunakan pendekatan student centered atau pembelajaran yang berpusat pada peserta didik. Pembelajaran dengan pendekatan ini memungkinkan peserta didik untuk aktif berperan serta dalam pembelajaran, sementara guru berperan sebagai fasilitator atau pembimbing.

Dengan demikian, pendidikan anti radikalisme di pesantren Amtsilati dilaksanakan dengan menggunakan dua sistem, yaitu sistem klasikal dan non klasikal. Pada sistem klasikal, pendidikan anti radikalisme dilaksanakan melalui pembelajaran di madrasah diniyah pasca Amtsilati. Sementara pada sistem non klasikal, pendidikan anti radikalisme dilaksanakan lewat pengajian dengan sistem bandongan yang diampu oleh pengasuh pesantren.

2) Materi pembelajaran

Selama ini, pendidikan anti radikalisme dilembagalembaga pendidikan, kebanyakan belum dilaksanakan secara terstruktur atau baku. Biasanya pendidikan anti radikalisme lebih cenderung disampaikan secara eksplisit melalui mata pelajaran seperti agama, sejarah, atau kewarganegaraan. Tidak ada materi khusus yang disampaikan karena memang sifatnya adalah hidden curriculum atau kurikulum tersimpan. Berbeda dengan PP. Darul Falah Amtsilati, pendidikan anti radikalisme di sana memiliki materi pembelajaran dan bahan ajar yang sudah baku. Bahan ajar tersebut berwujud buku karya KH. Taufiqul Hakim yang secara spesifik membahas tentang nilai-nilai moderatisme dan anti radikalisme dalam islam. Adapun materi yang terkandung dalam kitab Syifa'ul Ummah; menangkal Radikalisme tersebut antara lain:

\section{Islam agama moderat}

2. Islam melarang tindakan teror

3. Islam melarang tindakan radikal

4. Akar-akar radikalisme, meliputi tiga tema:

4.I. Merubah kemungkaran

4.2. Jihad fi sabilillah

4.3. NKRI sebagai negara kafir (Hakim, 20I6: 4) Materi-materi tersebut ditulis dalam bentuk 
syïiran dalam tiga bahasa, yakni bahasa Arab, Jawa, Indonesia, dan Inggris. Uniknya, untuk syïiran yang berbahasa Arab ditulis dengan harakat lengkap dan telah disertai makna gandul. Dalam tradisi pesantren salaf, buku seperti ini tentu dianggap aneh dan jarang ditemukan.

3) Metode Pembelajaran

Berdasarkan keterangan tersebut, metode pembelajaran dalam pendidikan anti radikalisme di PP. Darul Falah bisa dikategorikan menjadi beberapa metode, antara lain:

\section{a) Bandongan}

Salah satu metode yang digunakan dalam pendidikan anti radikalisme di PP. Darul Falah adalah metode bandongan. Bandongan adalah metode utama dalam sistem pembelajaran di pesantren. Dalam metode ini, sekelompok santri mendengarkan Kiai membaca, menerjemahkan, dan menjelaskan kitab. Setiap santri memperhatikan kitabnya dan membuat catatan-catatan baik makna maupun penjelasan dari sang Kiai Taufiq (Dhofier, 20II: 54).

Pada praktiknya, metode ini diterapkan dalam bentuk pembelajaran kitab Syifaul Ummah baik secara klasikal di madrasah diniyah pasca Amtsilati ataupun dalam bentuk pengajian secara non klasikal yang diampu oleh KH. Taufiqul Hakim. Kiai atau ustadz yang mengampu membacakan nadzam kemudian menerjemahkannya. Selanjutnya, Kiai memberikan penjelasan nadzam tersebut dan menyampaikan dalil al-Qur'an dan Hadits yang relevan dengan nadzam. Adapun santri cukup mendengarkan, memahami, dan membuat catatan-catatan atas penjelasan Kiai Taufiq yang dianggap penting. Hal ini berlaku baik dalam pengajian umum yang diampu oleh Kiai Taufiq maupun pembelajaran di madrasah diniyah pasca Amtsilati.

\section{b) Hafalan}

Hafalan adalah salah satu metode tradisional yang umum digunakan untuk belajar di pesantren. metode menghafal adalah suatu metode yang digunakan untuk mengingat kembali sesuatu yang pernah dibaca secara benar seperti apa adanya. Teknisnya, dalam metode ini peserta didik menghafal teks atau bait-bait yang terdapat dalam satu kitab, kemudian disetorkan kepada ustadz secara periodik atau insidental tergantung petunjuk ustadznya tersebut (Maksum, 2003: I00). Dalam bahasa Arab hafalan disebut muhafadzah yang berarti menjaga atau memelihara. Maksudnya, menghafal sama dengan menjaga atau memelihara sesuatu yang ada dalam ingatan.

Metode hafalan diterapkan dalam pendidikan anti radikalisme di Pesantren Amtsilati secara klasikal di madrasah diniyah pasca Amtsilati. Dalam pembelajaran kitab syifaul ummah, metode hafalan diterapkan dengan cara santri menghafal materi berupa dalil-dalil alQur'an dan hadits beserta nadzam yang tertulis dalam kitab tersebut secara mandiri. Pada tiap pertemuan, santri menyetorkan hafalan tersebut kepada ustadz yang mengampu kitab Syifaul Ummah.

\section{c) Takroran}

Kata takrar atau sering juga dibaca tikrar secara etimologi berarti mengulang atau mengembalikan sesuatu berulang kali (Ahmad, 2002: I26). Secara istilah tikrar sering diartikan dengan menyebutkan sesuatu dua kali berturut-turut atau lebih. Ada juga yang mengatakan tikrar adalah mengulangi suatu lafal atau padanannya untuk menetapkan makna (Ahmad, 2002: 127).

Dalam praktek pendidikan anti radikalisme, metode takroran dilaksanakan dengan melafalkan syïiran kitab Syifaul Ummah secara bersama-sama pada waktu-waktu tertentu. Biasanya Takroran ini dilaksanakan sebelum kegiatan pembelajaran dengan sistem bandongan sebagai bentuk apersepsi dan setelah shalat dhuhur berjama'ah. Terkadang takraran juga dilaksanakan sebelum shalat jama'ah lima waktu saat menunggu kedatangan imam shalat. Metode takroran ini tidak hanya diterapkan dalam pembelajaran kitab Syifaul Ummah tetapi juga dalam pembelajaran kitab-kitab lain.

\section{PENUTUP}

Setelah didapatkan data dari berbagai sumbernya kemudian dianalisis, maka bisa ditarik beberapa kesimpulan dari hasil penelitian ini bahwa PP. Darul Falah Amtsilati adalah Pondok Pesantren yang menerapkan dua sistem pendidikan, yaitu sistem pendidikan tradisional dan modern. Sistem pendidikan tradisional diterapkan melalui sistem pesantren dan madrasah diniyah, sementara sistem pendidikan modern diwujudkan dalam lembaga pendidikan formal mulai 
Madrasah Ibtidaiyah hingga Aliyah.

Sebagai pesantren dengan sistem salaf dan modern, PP. Darul Falah cukup serius dalam mencetak santri-santrinya menjadi muslim yang moderat. Hal ini dibuktikan dengan adanya pembelajaran yang difokuskan pada materi-materi anti radikalisme yang wajib diikuti santri. Pendidikan anti radikalisme dilaksanakan dengan dua model, yaitu klasikal dan non klasikal. Model klasikal dilaksanakan di madrasah diniyyah pasca amtsilati, sementara model non klasikal dilaksanakan lewat pengajian kitab setiap habis subuh dan maghrib. Adapun materi dan bahan ajar yang digunakan adalah kitab Syifa' aul Ummah yang ditulis oleh pengasuh, $\mathrm{KH}$. Taufiqul Hakim.

Metode yang digunakan dalam pendidikan anti radikalisme antara lain bandongan, hafalan, dan takroran. Bandongan digunakan dalam pengajian kitab dan pembelajaran di kelas. Hafalan biasanya dilaksanakan dengan cara menghafalkan nadzam secara mandiri lalu disetorkan kepada ustadz sebelum pembelajaran di kelas madrasah diniyah. Adapun takroran dilaksanakan dengan cara melafalkan nadzam bersama-sama baik sebelum pembelajaran ataupun setelah shalat fardlu.

\section{Daftar Pustaka}

Ahmad, Abu al-Husain, 2002, Maqayis alLughah, Jilid V, Beirut: Ittihad al-Kitab al-Arabi.

Darmadji, 2013, Tafsir al-Qur'an Tentang Teori Pendidikan Islam: Perspektif Pendidikan Islam di Indonesia, dalam Hermeneutik Jurnal Tafsir Hadits, Volume 9, Nomor I, Januari-Juni, 223-244.

Departemen Pendidikan dan Kebudayaan, I990, Kamus Besar Bahasa Indonesia. Jakarta: Balai Pustaka.

Dhofier, Zamakhsyari, 20II, Tradisi Pesantren: Studi Pandangan Hidup Kiai dan Visinya Mengenai Masa Depan Indonesia, Jakarta: LP3ES.

Hadi, Sutrisno, 1995, Metodologi Reseach, Yogyakarta: Andi Offset.

Hakim, Taufiqul, 2016, Syifa'ul Ummah: Menangkal Hal Radikal, Jepara: PP. Darul Falah.

Hornby, A.S., 2000, Oxford Advenced; Dictionary of Current English, UK: Oxford University Press.

Jazuli, Ahmad, 2016, Strategi Pencegahan
Radikalisme Dalam Rangka Pemberantasan Tindak Pidana Terorisme, dalam Jurnal Ilmiah Kebijakan Hukum, Volume IO, Nomor 2, Juli, Jakarta Selatan: Pusat Pengembangan Data dan Informasi Penelitian Hukum dan HAM RI. 197-209.

Kasjim, Salenda, 2009, Terorisme dan Jihad Dalam Perspektif Hukum Islam, Cet. I, Jakarta: Balitbang Diklat Depag RI

Maksudin, 2015, Pengembangan Metodologi Pendidikan Agama Islam Pendekatan Dialektik, Yogyakarta: Pustaka Pelajar.

Maksum, 2003, Pola Pembelajaran di Pesantren, Jakarta: Ditpekapontren Kelembagaan Agama Islam Departemen Agama.

Masduqi, Irwan, 2012, Deradikalisasi Pendidikan Islam Berbasis Khazanah Pesantren, dalam Jurnal Pendidikan Islam, Volume I, Nomor 2, 3-I4.

Moleong, Lexy J, I993, Metode Penelitian Kualitatif, Bandung: Remaja Rosda Karya.

Muqayyidin, Andik Wahyun, 2013, Membangun Kesadaran Inklusif-Multikultural untuk Deradikalisasi Pendidikan Islam, dalam Jurnal Pendidikan Islam, Volume II, Nomor I, Juni, I3I-I5I.

Nuh, Nuhrison M., 2009, Faktor-Faktor Penyebab Munculnya Faham Gerakan Islam Radikal di Indonesia, dalam HARMONI Jurnal Multikultural \& Multireligius. Volume VIII, Juli-September, 36-48.

Rokhmad, Abu, 2012, Radikalisme Islam dan Upaya Deradikalisasi Paham, dalam Jurnal Walisongo. Volume 20. No.I, Mei, 79-II3.

Rokhmad, Abu, 20I4, Pandangan Kiai Tentang Deradikalisasi Paham Islam Radikal di Kota Semarang, dalam Jurnal "Analisa" Pengkajian Masalah Sosial Keagamaan. Volume 2I, Nomor OI, Juni, Semarang: Balai Pengembangan dan Penelitian, hal. 27-37.

Shihab, Quraish, 2007, Wawasan Al-Qur'an. Jakarta: Mizan.

Sukmadinata, Nana Syaodih, 2009, Metode Penelitian Pendidikan. Bandung : Remaja Rosdakarya.

Tim Peneliti dari Kementrian Agama Kantor Wilayah Provinsi Jawa Tengah, 2015, Kebijakan Kementrian Agama dalam Pencegahan Ideologi Radikal, Semarang: Kementrian Agama Prov. Jateng.

Tim Penyusun Kamus, 2007, Kamus Besar Bahasa 
Indonesia, Edisi III, Cet. IV, Jakarta: Balai Pustaka.

www.amtsilatipusat.net, diakses pada tanggal 2

April 2017 pukul I4.00 WIB. 